\title{
PECULIARITIES OF TRUNK SKIN AND FAT FLEXURES CHANGES OF RURAL AND CITY YOUTH IN THE CONDITIONS OF THE EDUCATIONAL PROCESS
}

DOI: 10.36740/WLek202009221

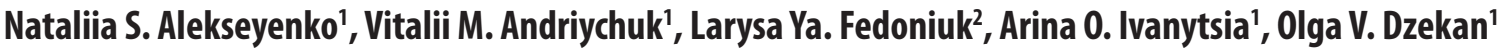 \\ 'NATIONAL PIROGOV MEMORIAL MEDICAL UNIVERSITY, VINNYTSIA, UKRAINE \\ 2. HORBACHEVSKY TERNOPIL NATIONAL MEDICAL UNIVERSITY, TERNOPIL, UKRAINE
}

\begin{abstract}
The aim: Determination of the peculiarities of annual changes in the thickness of trunk skin and fat flexures of rural and urban youth during educational process. Materials and methods: Were examined 200 healthy youths (100 residents of the village, 100 residents of the city) at their $1^{\text {st }}, 2^{\text {nd }}$ and $3^{\text {rd }}$ courses of study at the University of Life Safety using Shephard R. method.

Results: Based on the data obtained, the annual reduction of all trunk fat index values of rural and urban youth during their studies at the University of Life Safety were established. Comparing intra-group annual changes, they were drastically smaller in the first year of study, both in the rural group and in the locals' group.

Conclusions: During the course of the study, we found a decrease in all the supervised indicators in both groups. However, intergroup changes during the first year of study were significantly ostent.
\end{abstract}

KEY WORDS: fat thickness, trunk, youngers, citizens, villages

\section{INTRODUCTION}

Globalization is considered to be the driving force behind change in world processes. The main feature of the 21 st. globalization is that no country can develop and maintain its effective functioning beyond its borders through the interdependence of sectoral relations [1]. Medicine is not an exception. Particular attention is drawn to the medical industry in the context of the integration development of European countries. The effectiveness of the health care market is significant in the context of a long-term national strategy for socio-economic health policy [2,3]. Modern socio-economic conditions of life place high demands on the ability to work, the level of physical development and functional state of the organism of the young generation [4]. Physical development is a sign of human health [5]. Human, during the life development, goes through a series of consecutive stages, each of which is characterized by its traits and structure of mental activity, the relationship of the individual with the environment $[6,7,8]$. At the time of driving up to higher education, youngers reach only a certain level of physical maturity, which still continues to develop [9].

Determination of total body size makes it possible to assess the level of morpho-functional development, as well as to characterize the processes of growth and physical development of man [10].

Thus, today there are scientific works in which the influence of endogenous and exogenous factors on anthropometric parameters of youth are considered [11, 12].
However, there are no works in which the annual changes of somatometric parameters, namely indicators of trunk fat thickness of rural and urban residents under the educational process, are determined and compared.

\section{THE AIM}

Determination of the peculiarities of annual changes in the thickness of trunk skin and fat flexures of rural and urban youth during educational process.

\section{MATERIALS AND METHODS}

Were measured 200 practically healthy young men, 100 of whom were urban dwellers, the other 100 youngers were rural areas habitants. At the time of the examination, they were all studying at the School of Civil Protection at Lviv State University of Life Safety, which is the departmental higher education institution (university) of the first level of accreditation of the State Emergency Service of Ukraine (SESN). All surveyed youths lived in a dormitory, had a standard daily schedule and meals in accordance with the Charter of the Armed Forces of Ukraine, pedagogical process and physical activity of all youths were standard and corresponded to the specifics of the SES profile institution.

Commission on Bioethics of National Pirogov Memorial Medical University, Vinnytsya (report № 8 dated October 
$25,2018)$ established that the studies did not deny the main bioethical norms of the Helsinki Declaration adopted by the General Assembly of the World Medical Association, Council of Europe Convention on Human Rights and Biomedicine, relevant provisions of World Health Organization, International Council of Scientific Medical Societies, International Code of Medical Ethics and the laws of Ukraine and may be used in scientific work. All young people signed a form of informed consent. Participants were provided with anonymity and confidentiality of data.

The thickness of the students' fat layer was determined during the first and second years of study, using the Shephard R. method [13]. The were divided into 2 groups depending on the place of residence. Between the groups of rural and urban residents we compared the obtained somatometric indicators and studied the dynamics of these indicators over three years of study. The statistical processing of the obtained results using parametric and non-parametric methods was carried out using the standard computer program "STATISTICA 6.1". We determined the normality of the distribution of the data for each of the variations obtained, the average values for each of the studied traits, standard errors and deviations. Student's t-test was used to assess the significance of differences in indicators of both groups, with a value $\mathrm{p}<0.05$ the difference was considered significant.

\section{RESULTS}

The thickness of the fat layer under the scapula in the first year of study among the villagers was $4.68 \pm 1.19 \mathrm{~mm}$, the inhabitants of the city were smaller and equal to $4.53 \pm 1.20$ $\mathrm{mm}$. During the second-year study, the population of this village decreased by $0.73 \mathrm{~mm}$ and equaled $3.95 \pm 1.10 \mathrm{~mm}$, while in the city residents decreased to $4.04 \pm 1.19 \mathrm{~mm}$. In the third year, the thickness of the fat layer under the scapula in the inhabitants of the village and the city again decreased: in the peasants - up to $3.94 \pm 1.09 \mathrm{~mm}$, in the locals - up to $4.03 \pm 1.18 \mathrm{~mm}$. The average change in the thickness of the fat layer under the shoulder blade for the village youth in the first year of study was $(-0.73 \pm 0.06) \mathrm{mm}$ with a lowest amount value $(-3.00) \mathrm{mm}$ and a record gain of $0.50 \mathrm{~mm}$. This annual change in young men from the city equaled $(-0.49 \pm$ $0.07) \mathrm{mm}$ with minimum and maximum values $-2.50 \mathrm{~mm}$ and $1.50 \mathrm{~mm}$, correspondingly. In the second year of study, the difference in thickness of the fat layer under the scapular for city dwellers was $(-0.01 \pm 0.01) \mathrm{mm}$, with a smallest amount and highest value of $\pm 0.50 \mathrm{~mm}$. For the village dwellers the following indicators were: average - $(-0.01 \pm$ $0.01) \mathrm{mm}$, minimum - $(-0.50) \mathrm{mm}$, maximum $-1.00 \mathrm{~mm}$. The thickness of the fat layer under the scapula of the villagers during the training decreased by $0.74 \mathrm{~mm}$, with the main decrease was supervised in the first year of study, and the intra-group annual change of this parameter in the first year of study was drastically smaller by $0.72 \mathrm{~mm}$ compared to the annual change in the second year $(\mathrm{t}=11.08$ at $\mathrm{p}<0.05)$.

In town-people - decreased by $0.50 \mathrm{~mm}$ and yet again the main reduce was observed in the first year of study.
The annual change of this parameter in the first year of study is considerably slighter by $0.48 \mathrm{~mm}$ compared to the annual change in the second year $(\mathrm{t}=6.53$ at $\mathrm{p}<0.05)$. The inter-group annual change in the thickness of the fat layer under the scapula in the first year of study of the villagers was significantly smaller by $0.24 \mathrm{~mm}$ compared to the inhabitants of the city $(t=2.55$ at $\mathrm{p}<0.05)$.In the period of second year of study, the inter-group annual change of this thickness among the inhabitants of the village and the city was the same and there was no considerable difference.

The thickness of the fat layer in the abdomen area in the first year of study was $4.15 \pm 1.29 \mathrm{~mm}$ among the villagers, speaking about citizens, it was lower and equaled to $3.88 \pm$ $1.21 \mathrm{~mm}$. During the second-year study, the parameter had decreased by $0.51 \mathrm{~mm}$ with villages and equaled $3.64 \pm 1.17$ $\mathrm{mm}$, while in the city residents it reduced to $3.56 \pm 0.10 \mathrm{~mm}$. In the third year, the thickness of the abdomen fat layer in the inhabitants of the village and the city dwellers decreased again: up to $3.63 \pm 1.15 \mathrm{~mm}$ and up to $3.52 \pm 1.05 \mathrm{~mm}$ responsibly.

The average change of the fat layer thickness in the abdomen area for the village youth during the first year of study was $(-0.50 \pm 0.07) \mathrm{mm}$ with a bare minimum of $(-4.00) \mathrm{mm}$ and increase of $0.50 \mathrm{~mm}$. This annual change in young men from the city was equal to $(-0.31 \pm 0.07)$ $\mathrm{mm}$ with minimum and maximum values $(-3.50) \mathrm{mm}$ and $2.00 \mathrm{~mm}$, respectively. In the second year of study, the difference in the thickness of the fat layer in the abdomen for the villagers was $(-0.01 \pm 0.01) \mathrm{mm}$, with a minimum and maximum value of $\pm 1.00 \mathrm{~mm}$.

The thickness of the abdomen area fat layer of the village residents decreased by $0.51 \mathrm{~mm}$ during the study, with the main diminish observed during the first year of study, and the intra-group annual change of this parameter in the first year of study was significantly minor by $0.49 \mathrm{~mm}$ comparing to the annual change in the second year $(\mathrm{t}=$ 6.54 at $\mathrm{p}<0.05)$. Town- people - showed the derision by 0.35 $\mathrm{mm}$ and the main drop off was observed in the first year of study. The annual change of the parameter during the $1^{\text {st }}$ year of study was extensively greater by $0.27 \mathrm{~mm}$ compared to the annual change in the $2^{\text {nd }}$ year $(t=3.67$ at $\mathrm{p}<0.05)$.

The inter-group annual change of the abdomen fat layer thickness in the first year of villagers' education was smaller by $0.20 \mathrm{~mm}$ compared to the residents of the city, and in the second year - the inter-group annual change of the thickness in the villagers was greater by $0.03 \mathrm{~mm}$ compared to the city residents. It should be noted that this annual change in the first and the second year of study when comparing the groups of young people did not demonstrate a significant difference.

The thickness of the fat layer on the trunk side of the first-year villagers was $4.33 \pm 1.30 \mathrm{~mm}$, as for the city inhabitants, it was smaller and equaled $3.93 \pm 1.35 \mathrm{~mm}$. It should be noted that this thickness of the skin-fat layer in the villagers turned out to be drastically greater by 0.40 $\mathrm{mm}$ compared to the citizens $(\mathrm{t}=2.16$ at $\mathrm{p}<0.05)$. During the second-year study, the size of the village residents decreased by $0.58 \mathrm{~mm}$ and equaled $3.75 \pm 0.80 \mathrm{~mm}$, while the residents of the city - slowed down to $3.52 \pm 0.90 \mathrm{~mm}$.In the third year, the thickness of the fat layer on the villag- 
ers 'trunk side increased and, in the citizens, - decreased: up to $3.77 \pm 1.13 \mathrm{~mm}$ and $3.50 \pm 1.12 \mathrm{~mm}$ respectively. The measurements on the $3^{\text {rd }}$ year showed the increasing villagers thickness fat layer of the trunk side and derision of the parameter for city dwellers: - up to $3.77 \pm 1.13 \mathrm{~mm}$ and to $3.50 \pm 1.12 \mathrm{~mm}$ respectively.

The average change in the thickness of the fat layer on the side for village youth in the first year of study was $(-0.58 \pm 0.08) \mathrm{mm}$ with a minimum value of $(-3.50) \mathrm{mm}$ and a maximum gain of $1.00 \mathrm{~mm}$. This annual change in youths from the city was equal to $(-0.40 \pm 0.09) \mathrm{mm}$ with minimum and maximum values of $-3.00 \mathrm{~mm}$ and 3.00 $\mathrm{mm}$, respectively.

In the second year of study, the difference in the thickness of the trunk side fat layer for the villagers was $0.03 \pm$ $0.02 \mathrm{~mm}$ with a minimum and maximum value of \pm 1.00 $\mathrm{mm}$. The following indicators are characterized for city dwellers: average - $(-0.02 \pm 0.01) \mathrm{mm}$, minimum - $(-1.00)$ $\mathrm{mm}$, maximum $-1.00 \mathrm{~mm}$.

The thickness of the fat layer on the side of the village residents during the training decreased by $0.55 \mathrm{~mm}$, by the way, the lessen was observed only in the first year of study, and the intra-group annual change of this parameter in the first was appreciably smaller by $0.61 \mathrm{~mm}$ compared to the annual change in the second year $(\mathrm{t}=7.27$ at $\mathrm{p}<0.05)$. As for the citizens, it decreased by $0.42 \mathrm{~mm}$ and the main drop off was observed in the first year of study. The annual change of this parameter in the first year of study was significantly smaller by $0.38 \mathrm{~mm}$ compared to the annual change in the second year $(\mathrm{t}=3.93$ at $\mathrm{p}<0.05)$.

The inter-group annual change in the thickness of the fat layer on the trunk side during the first year of villagers' education was lesser by $0.18 \mathrm{~mm}$ compared to the residents of the city. As for the second year of study, the inter-group annual change of this thickness among the villagers was already greater by $0.05 \mathrm{~mm}$ compared to the locals. It should be noted that this annual change in the first and the second year of study, when comparing the groups of young people was a noteworthy different.

\section{DISCUSSION}

Anthropology is the science of a person that studies human biology, ethnography, physical organization and their changes in time and space, polymorphism of biological human organization at the individual and population levels under the influence of evolution, constitutional features and physical development [5]. Anthropometric parameters of youngers as well as changes of these indicators were studied by other scientists. Thus, when comparing the data obtained by us (indicators of the thickness of young city and village dwellers body fat layer) with the results of studies another sicentists we had found that no significant difference appeared between the results $[14,15,16]$. Due to the fact that the young people we examined, were in the same conditions of surrounding area influence and educational process, which was due to the uniformity of approaches to the organization and intensity of physical and mental load, belonging to rural or urban resi- dence becomes a dominant factor. There are quite a number of studies aimed at examining the effects of habitat and residence conditions on physiological and psychological parameters. Such studies are usually conducted on groups of students or students of individual educational institutions [17]. In contrast to the above works, we obtained the results of the study of the parameters of the thickness of the fat layer of the trunk in the educational process and compared the changes of intragroup parameters during the period of studying. By the way, intergroup variations in these indicators and the characteristics of changes in rural and urban youth during training were identified.

\section{CONCLUSIONS}

The following differences were identified while comparing the changes in the thickness of the trunk fat layer under the influence of the educational process.

Parameters of the young men trunk thickness during the first year of study among the villagers turned out to be greater than that one of the city residents.

During the investigation, all the studied parameters decreased in both groups of youngers.

The intergroup indices of the annual change in the thickness of the trunk fat layer during the first year of education for the villagers were smaller compared to the inhabitants of the city, and the thickness of the fat layer under the scapula had drastically valuable changes.

The thickness of the fatty layer of the extremities, as well as the total and partial body sizes of rural and urban youths, are needed further, followed by a comparison of their annual changes during academic year.

\section{REFERENCES}

1. Fedun I.L., Generalov 0.V. Ekonomichna globalizaciya ta formuvannya mizhnarodnih virobnichih merezh [Economic globalization and formation of international production networks]. Economy and society. 2018; 15: 71-7. (in Ukrainian).

2. Yanchak J. Efektivnij rozvitok ta funkcionuvannya rinku medichnih poslug v umovah globalizaciyi ta integracijnih procesiv u ohoroni zdorov'ya [Effective development and functioning of the health care market in the context of globalization and integration processes in health care]. Bulletin of Lviv Polytechnic National University. Avg. Law. 2017;1:227-35. (in Ukrainian).

3. Burgess-Pinto E., Yastremska S.O., Fedoniuk L.Ya. et al. Sustainable development principles in health promotion and nursing education. Medical Education. 2019; 4:67-73.

4. Barybina L.N. Analiticheskij obzor nauchnyh issledovanij po probleme individualizacii fizicheskogo vospitaniya v vysshem uchebnom zavedenii [Analytical review of scientific research on the problem of individualization of physical education in higher education]. Pedagogy, Psychology, and Biomedical Problems of Physical Education and Sport: Coll. of sciences. works edited by prof. S.S. Yermakova. 2012; 9:14-9. (in Russia).

5. Andriychuk V.M. Zakonomirnosti formuvannya pokaznikiv fizichnogo rozvitku yunakiv pid chas navchannya u vishih navchalnih zakladah [Regularities of formation of indicators of physical development of young men during training in higher educational establishments]. 2017:34. (in Ukrainian). 
6. Vinué G. An R Package for Analysis of Anthropometric Data. Journal of Statistical Software. Anthropometry. 2017; 77(6).

7. Lyubomirskaya K.S., Kamyshnyi A.M., Krut Yu.Ya. et al. SNPs and transcriptional activity of genes of innate and adaptive immunity at the maternal-fetal interface in woman with preterm labour, associated with preterm premature rupture of membranes. Wiadomości Lekarskie. 2020; 73(1):25-30.

8. Khmara T.V., Fedoniuk L.Ya., Sarafiniuk L.A et al. Structural Organization of Trachea and Primary Bronchus of the 7-10 Months' Fetus. World of the Medicine and Biology. 2019;3(69):230-233.

9. Kurlyand Z.N. Pedagogika vishoyi shkoli [Pedagogy of high school]. Kiev: Science; 2010: 495 . (in Ukrainian).

10. Skoblina N.A. Fizicheskoe razvitie detej: fundamentalnye i prikladnye aspekty [Physical development 0 children: fundamental and applied aspects]. Moscow: Union of hygienists; 2018: 179. (in Russia).

11. Pomohaci M., Sopa I.S. The importance of anthropometry measurements in analyzing the impact of sports activities on students. Revista academiei for telorterestre. 2017; 1(85):40-48.

12. Shaparenko P.P. Antropometrichna tasomatotipologichnaharakterimstika praktichno zdorovih miskih pidlitkiv oboh statej ukrayinskoyi etnichnoyi grupi [Anthropometric and somatotypologica Icharacteristics of practically healthy urban adolescents of both sexes of the Ukrainian ethnic group]. Bulletin of Morphology. 2006; 8(1): 339-41. (in Ukrainian).

13. Shephard R. Bodycompositioninbiological. Cambridge: Cambridge University Press; 1991: 348.

14. Lescay N.R., Becerra A.A., González A.H. Anthropometry. Comparative analysis of technologies for the capture of anthropometric dimensions. Revista EIA. 2016; 26:47-59.
15. Shpakova N.A., Tyholaz V.0., Guminsky Yu.J. et al. Porivnyalnij analiz bazovih antropometrichnih pokaznikiv yunakiv (17-18 rokiv) 1994 - 2006 rokiv Podilskogo regionu Ukrayini [Comparative analysis of basic anthropometric indicators of boys (17-18 years) of 1994-2006 in the Podillya region of Ukraine]. Ukrainian morphological almanach. 2011;3:143-145. (in Ukrainian).

16. Anczewska M., Charzynska K. Educational assessment of pupilsin Poland. Educ. Journal. 2012;9(1):11-9.

17. Bolsheva A., Sidorov D., Bogomolova E. Monitoring of physical development indicators of Nizhny Novgorod school children (1980-2012 years). International Student Congress; 2014 July 10-12th; Graz, Austria. 2014. Austria.

The work is carried out within the framework of the initiative research work of the E.Pirogov Vinnitsa National Medical University (Vinnitsa, Ukraine) "0114U000990 The influence of exogenous factors (socio-economic, ecological, geological, territorial) on anthropometric parameters and physiological indicators of adolescents".

\section{ORCID and contributionship:}

Nataliia S. Alekseyenko: 0000-0003-3137-7436 ${ }^{B, D}$

Vitalii M.Andriychuk: 0000-0001-8984-3028 A, C

Larysa Ya. Fedoniuk: 0000-0003-4910-6888 ${ }^{\mathrm{F}}$

Arina O. Ivanytsia: 0000-0002-5296-7075 ${ }^{\mathrm{E}}$

Olga V. Dzekan: 0000-0002-4115-9638 ${ }^{\mathrm{E}}$

\section{Conflict of interest:}

The Authors declare no conflict of interest.

\section{CORRESPONDING AUTHOR Larysa Ya. Fedoniuk}

I. Horbachevsky Ternopil National Medical University

9 Valova st., 46000 Ternopil, Ukraine

tel: +380673999143

e-mail: Fedonyuk22Larisa@gmail.com

Received: 19.04 .2020

Accepted: 28.07 .2020
A - Work concept and design, B - Data collection and analysis, C - Responsibility for statistical analysis,

D-Writing the article, $\mathbf{E}$-Critical review, $\mathbf{F}$ - Final approval of the article 